\title{
FRANTIŠEK ŠKVRNDA:
}

\section{Sokratovská otázka ako problém historiografie antickej filozofie}

\author{
Bratislava: Univerzita Komenského v Bratislave 2020, 94 s.
}

Monografia Sokratovská otázka ako problém historiografie antickej filozofie predstavuje v našom česko-slovenskom akademickom prostredí prvú komplexnejšiu prácu, venovanú problematike historiografie sokratovskej filozofie. $\mathrm{Z}$ formálneho hl'adiska sa práca pohybuje na rozmedzí dejín filozofie a klasickej filológie, pričom miestami pojednáva o otázkach spojených s dejinami literatúry a literárnej kritiky. Hlavným ciel'om monografie je systematicky uchopit' problematiku takzvanej sokratovskej otázky. Ako je všeobecne známe, historický Sokrates po sebe nezanechal žiadne filozofické spisy, z ktorých by sme mohli čerpat' historicky hodnoverné informácie o jeho myslení a názoroch. Tie získavame až sprostredkovane, z textov pomerne širokej a rôznorodej skupiny antických autorov. Sokratovská otázka smeruje k tomu, ako uviest' do súladu všetky rozmanité, niekedy aj na prvý pohl'ad protirečiace svedectvá antických autorov, ktorí o Sokratovi písali a tradovali jeho myšlienkový odkaz d'alším generáciám (s. 12 - 13).

Práca je rozdelená do dvoch hlavných kapitol. Prvá z nich má polemický charakter. Autor sa v nej usiluje vyvrátit' námietky skepticky orientovaných historikov antickej filozofie, ktorí zastávajú názor, že historického Sokrata vôbec nemožno spoznat a že by sme teda mali meno „Sokrates“ odstránit' z historiografie antickej filozofie. Postupne analyzuje tri druhy argumentov, ktorými moderní bádatelia zdôvodňujú svoje radikálne vyškrtnutie Sokrata z učebníc dejín filozofie. Prvým argumentom je, že Sokrates po sebe nezanechal žiadny spis, a tak neexistuje žiadny základný referenčný bod, ktorý by odkazoval na jeho vlastné myšlienky, presvedčenia a životné zásady. Druhý argument je založený na dokazovaní, že hlavný zdroj správ o Sokratovi, takzvané sokratovské rozhovory (sokratikoi logoi), obsahuje vel'a anachronizmov, výmyslov a vôbec nereflektuje dejinné udalosti ani neopisuje reálne historické postavy. Ak v tejto literatúre - kam, mimochodom, zarad’ujeme aj autorov, akými sú Xenofón a Platón - nenachádzame žiadny historický opis Sokrata, musíme tieto správy označit' len za dielo básnickej predstavivosti, ktoré nemá s historickou osobou Sokrata nič spoločné. Po tretie, údajne už sám Aristoteles označil sokratovskú literatúru za dielo takzvaného mimetického umenia, teda za fiktívny literárny žáner. 
Autor dospieva k záveru, že ani jeden z týchto argumentov nemožno považovat' za plauzibilný. Pri detailnejšom rozbore textov, na ktoré sa skeptickí bádatelia odvolávajú, sa naopak ukazuje, že v gréckej filozofickej literatúre neexistuje jasná definícia autorského textu ako takého (s. 21 - 27). Absencia pôvodného Sokratovho textu tak podl'a Škvrndu nepredstavuje žiadny problém, pretože keby sme len na základe tohto jedného ukazovatel'a mali definovat' historicitu antických filozofov, museli by sme z dejín odstránit' aj také osobnosti ako Platón, Aristoteles, Plotinos či vel'a d’alších významných postáv.

Druhá čast' prvej kapitoly sa zameriava na problematiku takzvanej antisokratiky, literárneho žánru, z ktorého sa nám zachovalo len niekol'ko fragmentov v diele Aténaia z Naukratidy Hodujúci sofisti. Podla týchto fragmentov dialógy Platóna a d'alších sokratovcov predstavovali fiktívne príbehy, ktoré sa nemohli odohrat' v reálnom čase s reálnymi l'ud'mi. Škvrnda identifikoval celkovo osem takýchto argumentov, ktoré poukazovali na fiktívny charakter sokratovskej literatúry. Pri každom argumente sa usiluje historicko-filologickou analýzou poukazovat' na to, že všetky argumenty, ktoré nachádzame v antisokratike, sú nedôveryhodné a zavádzajúce. Predstavujú len dobovú chronique scandaleuse, namierenú proti Platónovi a sokratovským filozofom vo všeobecnosti. Argumenty antisokratiky preto nemožno pokladat' za platné - ide o zavádzajúce dezinterpretácie historických udalostí a faktov, ktoré protirečia dostupnej historickej evidencii (porov. s. $31-41$ ).

$\mathrm{V}$ tretej časti prvej kapitoly sa v súvislosti s problematikou fiktívneho charakteru sokratovskej literatúry analyzuje ešte jedna významná pasáž, ktorá pochádza z Aristotelovej Poetiky. Autor analýzou textu dospieva k záveru, že v tejto pasáži Aristoteles spomína sokratovskú literatúru ako dielo mimetického umenia, avšak bližšie nedefinuje, o aké dielo tohto umenia ide - či o také, ktoré zachytáva realistické prvky a popisuje to, čo sa niekedy v minulosti skutočne aj odohralo, alebo také, ktoré konštruuje dej na spôsob epickej alebo tragickej literatúry. Vzhl'adom na absenciu tejto klúčcovej charakteristiky podla Škvrndu pasáž z Aristotelovej Poetiky nemožno vnímat' ako „dôkaz“, ktorý by potvrdzoval fiktívnu povahu sokratovskej literatúry. O historickosti alebo fiktívnosti sokratovskej literatúry Aristoteles totiž nehovorí vôbec nič.

Prvá kapitola dospieva k záveru, že argumenty skepticky orientovaných bádatelov pri detailnejšej analýze neobstoja. Skeptickí musíme byt' predovšetkým voči samému skepticizmu - antické texty ani povaha antickej literatúry totiž neobsahujú žiadne jednoznačné dôvody a svedectvá, na základe ktorých by sa dalo jednoznačne skonštatovat', že historický Sokrates je navždy stratený a neprístupný akémukol'vek historickému skúmaniu.

Druhá kapitola opúšt’a svet klasickej literatúry a sústred’uje sa na dejiny filozofie, najmä na recepciu Sokratovej postavy a filozofie v dielach historikov filozofie. 
Prostredníctvom najvýznamnejších interpretačných tradícií poukazuje na to, ako sa postava Sokrata nekriticky interpretovala $\mathrm{v}$ duchu jednotlivých kultúr, $\mathrm{v}$ ktorých historici žili a pôsobili. V renesancii a novoveku stelesňoval ideál novoplatónskeho mudrca, neskôr bol vzorom karteziánskeho skepticizmu. V devätnástom storočí sa pod vplyvom Schleiermachera a Zellera Xenofón začal vnímat' ako privel'mi jednoduchý, nefilozofický typ autora, ktorý nevedel vystihnút' zložité filozofické myšlienky Sokrata a celú jeho filozofiu nivelizoval na spôsob neodborného a nešikovného prekladatel'a, ktorý preloží majstrovsky zložené básnické verše do suchopárnych oznamovacích viet. Namiesto Xenofónta sa záujem postupne sústredil na Platóna a jeho verziu Sokrata, ktorá mala pre nich „väčšiu“ filozofickú hodnotu, pretože lepšie odrážala dobové hegeliánske filozofické charakteristiky. Platóna uprednostnila aj anglosaská historiografia filozofie v dvadsiatom storočí. Pod vplyvom prác Gregoryho Vlastosa sa historický Sokrates začal spájat's postavou takzvaných raných, aporetických Platónových dialógov. V anglosaskom prostredí sa zo Sokrata napokon stal filozof analytického razenia, ktorý uvažuje ako anglický džentlmen, a nie ako Aténčan z piateho storočia pred naším letopočtom (s. 62 - 63). Každá historická epocha si Sokratov obraz prispôsobovala svojmu mysleniu, čo sa následne premietlo aj do historiografie. Túto skutočnost' Škvrnda označuje za hlavný problém modernej historiorafie antickej filozofie. Na jednej strane niektorí bádatelia zaujímajú neopodstatnený a prehnaný skepticizmus, na druhej strane si tendenčne vyberajú len jeden typ správ, alebo jedného autora, ktorého portrét vyhlásia za autoritatívny. Všetky d’alšie správy, ktoré nie sú v zhode s preferovaným autorom a portrétom Sokrata, vylučujú argumentmi ad hominem ako nedôveryhodné (s. 67).

V závere monografie sa dočítame, že sokratovská otázka ako problém historiografie antickej filozofie nemôže byt' nikdy úplne zodpovedaná. Sokrates sa tak podl'a autora nachádza „, král'ovstve krivých zrkadiel““. Napriek tomu vyjadruje potrebu hl'adat' možnosti a spôsoby, ako aspoň čiastočne zodpovedat' sokratovskú otázku. Vzhl'adom na vel'ké množstvo komparatívneho textového materiálu, ktorý sa o Sokratovi zachoval, existujú jej plauzibilnejšie a menej plauzibilné riešenia, ktoré predpokladajú isté interpretačné metódy a pravidlá. Autor upozorňuje, že v súčasnosti existuje viacero interpretačných prúdov a historikov filozofie, ktorí sa usilujú aplikovat tieto princípy pri hl’adaní historického Sokrata a dospievajú k zaujímavým, v historiografii antickej filozofie doteraz ešte neartikulovaným riešeniam sokratovskej otázky. Monografia reflektuje aj aktuálny stav riešenej problematiky v zahraničí a ponúka čitatel'ovi rozbor najvplyvnejších interpretácií sokratovskej filozofie, aké boli od začiatku dvadsiateho prvého storočia predložené. 
Po obsahovej stránke je Škvrndova monografia vel’mi obsiahla. Autorov slovník udržiava stred medzi abstraktnou náročnost'ou, stručnost’ou a plynulým historiografickým naratívom. Každé tvrdenie podopiera odkazmi na primárnu alebo sekundárnu literatúru, čím vzniká bohatý poznámkový aparát. Argumenty obsiahnuté v monografii sú plauzibilné a vyvážené. Autor nemieni za každú cenu argumentovat' len v prospech jedného, vopred zadefinovaného stanoviska. Nehl'adá pozitívnu odpoved' na to, kto bol historický Sokrates, aké boli jeho názory alebo zvyky. Zámerom predkladanej monografie je odhalit' hermeneutické predpoklady, s ktorými pracuje historiografia antickej filozofie už od svojho vzniku. Práca systematicky poukazuje na rôzne predsudky a chyby v interpretáciách Sokratovej filozofie a osobnosti, či už ide o interpretácie starších, alebo novších autorov.

Azda jediným nedostatkom monografie je jej krátky rozsah čo do počtu strán. Autor prezentuje svoje argumenty a závery v minimalistickom formáte. $Z$ tohto dôvodu by práca mohla byt' viac rozšírená a niektoré problémy viac artikulované. Vzhl'adom na úsilie zhrnút' všetky moderné interpretačné tradície by monografia mohla byt' doplnená aj o myšlienky talianskych alebo francúzskych historiografov, ktorí sú v nej zastúpení viac-menej okrajovo. V prípade druhého vydania monografie by bolo vítané, keby autor rozsah publikácie rozšíril a doplnil ju o záverečné indexy a registre, ktoré by odborníkom umožnili l'ahšiu orientáciu v texte. Napriek týmto výhradám môžeme skonštatovat', že práca spíňa všetky štandardy odborných publikácií a predstavuje zaujímavý a originálny príspevok do oblasti štúdií antickej filozofie $\mathrm{v}$ našom akademickom prostredí.

Zuzana Zelinová

Univerzita Komenského v Bratislave

Filozofická fakulta

Katedra filozofie a dejín filozofie

Šafárikovo námestie 6

81499 Bratislava

Slovenská republika

e-mail: zelinova9@uniba.sk

ORCID ID: https://orcid.org/0000-0002-5316-8929 